Article

\title{
Reimagining the Educational Field: Thoughts on a Critical Criminology of Education
}

\section{Karl Guebert}

Department of Criminology, University of Ottawa, 120 University Street, Ottawa, ON K1N 6N5, Canada; E-Mail: karlguebert@gmail.com

Academic Editor: Jon Frauley

Received: 4 March 2015 / Accepted: 6 May 2015 / Published: 14 May 2015

\begin{abstract}
Prompted by the need to expand the criminological enterprise, this paper makes a case for a critical criminology of education, one that takes a governance approach. It seeks to illustrate what such a criminology might entail by developing an analytic framework with which to analyze the educational field. The framework is put to use to provide an analytic discussion of Ontario education policy reformations concerning student discipline. Education was conceptualized by policymakers as an institution for disciplining and governing students, specifically through the concept of "bullying". From this analysis, the paper suggests it is possible to theorize education as a "security apparatus", one that is increasingly concerned with the governance of social (in)security and public safety. The discussion suggests that education is an important institution for governing by identifying one regulatory project that concerns student behavior both within and beyond the school. In so doing, the paper illustrates the creative process in developing a criminology of education, and the value of imaginative thinking within criminology.
\end{abstract}

Keywords: critical criminology of education; imaginative criminology; governance; theory

\section{Introduction}

The notion of a criminology of education will likely arouse some degree of confusion or doubt among criminologists. Surely, some would ask, "What does education have to do with criminology?" (At several points, colleagues in the Department of Criminology have confronted me with this question.) This raises further questions about the status of criminology as a discipline and what object(s) of inquiry it is organized around. Education has not been left totally untouched by 
criminologists. One might look to Albert Cohen’s [1] seminal work Delinquent Boys. Cohen points to the school as one milieu (among other custodial agencies such as, settlement houses, extra-curricular activities, etc.) which functions in a way to generate delinquent subcultures; that is, the school is a situation in which children compete for "status" according to middle-class values and thus produces “failures” in need of a “solution” [1] (pp. 112-119). However, Cohen’s book is primarily a study on delinquent subculture as an outgrowth of mainly working-class conditions in which the school is implicated, and not a criminological study of the school (or education) itself.

More recently, criminologists have concerned themselves more directly with education, but for the most part the literature is evaluative and indebted to a positivist epistemology and quantitative methods, studying the effectiveness and efficiency of the school as a site for the application of crime prevention strategies (e.g., [2-4]). There have also been some "critical” studies of education within criminology, but this has largely been limited to criminologists interested in educational programs for prisoners and tends to be descriptive and normative (e.g., [5,6]), though this area has also been studied for evaluative purposes (e.g., $[7,8]$ ). What these works have in common is a narrow conception of what object of study criminology is organized around: namely, the domains of criminal law, punishment, and criminal justice. Although these are important objects for study, this traditional, "myopic” focus on "police-courts-corrections" is what John Braithwaite [9] (p. 230) suggests has situated criminology as a discipline "destined for decline," or one restrained by the "straightjacket of crime-ology" [10] (p. 175). These traditional topics, then, act as boundaries for the discipline of criminology that (for some, at least) must be challenged and expanded in order to understand newer, and perhaps more relevant, modes of governance and control in contemporary capitalist societies. That is, the effort should be of taking a broader perspective to focus our attention on strategies of governance and regulation.

So, the possibility of thinking about a criminology of education that does not prioritize the criminal justice system or treat criminal justice as a separate domain, depends essentially on what one thinks “criminology" means. Here, a critical criminology, following others (see, for example, [10,11]), means taking governance and social ordering as concerns for criminological understanding. In this sense, a critical criminology of education is the result of an imaginative endeavor, thinking creatively not only about the discipline itself, but also about the literature one employs and the empirical objects one studies. If we take seriously the notion that the criminal justice system plays only a limited role in governing contemporary society, and even controlling crime [12-16], one logical step to take is to avail ourselves of the emerging realities concerning education, which a governance approach to criminology permits. It should be noted that a governance framework has been forwarded by some criminologists as an apt way of coming to terms with social control and regulation beyond criminal justice, particularly in the work of David Garland [13,14,17] and Malcolm Feeley and Jonathan Simon [18-20]. I follow this path in thinking about how we can reimagine educational systems criminologically.

In this paper, following from the above, I hope to make a case for a critical criminology of education, one that specifically takes an "education as governance" approach (see [21]). In so doing, it aims to demonstrate the value of a governance framework to the criminological study of education. I do this by illustrating what such a criminology may look like or entail. I begin with the social, political and economic context of Western capitalist states in order to outline trends in the governance of these societies. This prompts a brief discussion of the concepts of discipline and governance following Michel Foucault and Pierre Bourdieu. I then consider some of the education literature to 
further situate the institution of education within this governmental context. Lastly, I discuss recent Ontario educational policy reformations insofar as this demonstrates the capacity for my analytic framework to offer a novel understanding of the educational field.

\section{Post-Social Governance and Education}

\subsection{Broader Trends}

The "social" model of governance, embodied by the broad social welfare system, has given way to a "leaner" model that is heavily individualized, widely known as "neoliberalism" [22-25]. As a result, new conceptions of security and citizenship have emerged that have implications for governing in these societies. This context has also been termed a "post-social” state [26] or "active society" [25], in which individuals are responsibilized for managing their personal well-being, primarily through activity within markets [13,14,24,27-29]. A significant outcome has been the reconfiguration of the crime control field to suit this political context. As David Garland [13] (p. 451) puts it, states have increasingly approached crime control in ways that aim to "modify the everyday routines of social and economic life by limiting the supply of opportunities, shifting risks, redistributing costs, and creating disincentives. It aims to embed controls in the fabric of normal interaction.” Security is thus contingent upon one's ability to self-regulate. This is considered an "adaptive strategy" by Garland [14], which points to the state governing crime through employing the capacity of smaller units to take on more responsibility in this regard. The concept of "community" has been central in these new strategies of safety and security, undermining the "social" as the main category of governance or the main way of understanding the role of state governments [14,26,28] (see also [30]).

A particular conceptualization of citizenship pervades the post-social political context that corresponds with the enterprise culture which it promotes by way of what Sears [24] would term a lean disciplinary regime. Lean discipline seeks to instill the "ethos of the lean person” [24] (p. 99) which compels individuals to be "active" (see [25]) in order to rely on the marketplace to meet their needs. Along with increased responsibility bestowed upon individuals, citizenship in a post-social state requires individuals to practice "privatized actuarialism," or as O'Malley [31] (p. 197) terms it, "prudentialism”. To be prudent means taking the necessary steps to secure one's self economically. Thus, prudential subjects will also comport themselves as enterprising selves. Enterprise, according to Rose [32] (p. 145), “designates a kind of organizational form” while also "more generally provid[ing] an image of a mode of activity to be encouraged in a multitude of areas of life" (see also [33]). Life becomes a project which must be constantly worked on it order to achieve a planned outcome, notably the construction of a personal safety net [31] (p. 197). Enterprising selves, comporting themselves according to the principles of prudentialism, are also suggested to be empowered subjects, which is to say they have an enhanced self-esteem. As Barbara Cruikshank suggests, self-esteem is

a practical and productive technology available for the production of certain kinds of selves ... Self-esteem is a technology in the sense that it is a specialized knowledge of how to esteem our selves, to estimate, calculate, measure, evaluate, discipline, and to judge our selves [34] (p. 329). 
Thus, self-esteem is an important component in governing, as it is a precondition for the empowerment of individuals which in turn compels one to accept responsibility and be prudent. As Rose [15] (pp. 334-335) notes, "High self-esteem is linked to the power to plan one’s life as an orderly enterprise and take responsibility for its course and outcome." Enterprising selves are created through empowering subjects to conduct themselves and regulate their lives according to appropriate ends.

What the notions of empowerment, responsibilization, prudentialism, and so on pertain to are the concepts of "discipline” (at the level of individuals) and "governance” (at the level of aggregates). This combination of discipline and governance resonates with Foucault's [35] (p. 139) notion of "a biopolitics of the population," a form of politics that is at once concerned with the processes of population and the behaviors of subjects. Governmental biopower operates by disposing of things, via tactics, in order to lead to "convenient" ends concerning matters of the population's welfare $[35,36]$. Governance for Foucault [37] (p. 790) is a matter of "structur[ing] the possible field of action of others." Government is not solely a "State" enterprise (though this does not mean that the state's role is eradicated; it has been "governmentalized”), but rather a complex of techniques, strategies, authorities, institutions, and the like. These various actors and the tactics they deploy, rather than constraining individuals, endeavor the “'making up' [of] citizens capable of bearing a kind of regulated freedom” so that citizens "play a part in [political power's] operations” [29] (p. 174). Government may be practiced differently depending on the governmental rationality, which constitutes a particular mode of governance. Thus, the discussion above has outlined the mode of governance widely known as "neoliberalism".

However, governmental power makes up only one part of biopolitics, which also involves disciplinary power. As Foucault [36] (p. 102) puts it, "the managing of a population not only concerns the collective mass of phenomena, the level of its aggregate effects, it also implies the management of population in its depths and its details." Discipline operates as "an infinitesimal power over the active body" in order to render it docile and useful [38] (p. 137). "Discipline 'makes' individuals” by way of its "training” function [38] (p. 170). As Foucault [38] (p. 172) suggests, the school building itself was conceived as a "mechanism for training" in that it could effectively employ the disciplinary techniques of "hierarchical observation”, “normalizing judgment”, and "the examination”. These techniques are exercised through mundane practices, constituting discipline as a mode of power that is modest, yet also one with enormous reach in that it creates particular kinds of subjects and ways of knowing and acting upon those subjects.

Foucault's work on discipline elucidates mainly the institutional processes of governing individuals' conduct. I suggest that Bourdieu's concepts of field and capital can help to supplement Foucault's account in that they provide further insight into the processes of governance and outcomes of discipline (for a helpful comparison between Foucault and Bourdieu, see [39] pp. 40-42). Bourdieu envisions the social world as comprised of relatively autonomous fields of action, one field being the educational field. The field is a "field of forces," a social space made up of a set of power relations that produces practices without being the result of the subjective intentions of individual agents [40] (p. 724). That is, fields are structured spaces with sets of regularities and understandings; “a world of already realized ends_-procedures to follow, paths to take” [41] (p. 53). Each separate field produces a particular form of what Bourdieu terms "cultural capital”. Cultural capital may exist in an "embodied state," which "presupposes a process of embodiment, incorporation" requiring an investment of time and effort on the agent's part [42] (p. 243). Thus, the educational field, through governing student subjects 
along the lines drawn by Foucault, provides a space, or a market of sorts, for the distribution and acquisition of "educational capital” (see also [21]). Capitals are forms of power, allowing agents to act and know; however, the power derived from capital (of any kind) is contingent upon the field in which it functions. Thus, in order for a capital to have any effect, or hold any value, it must be in alignment with the demands of the field in which the agent operates or will operate. As we have seen, developments in the governance of contemporary capitalist societies have reoriented institutions (such as crime control, education, etc.) to be concerned with producing populations of a particular sort of citizen, one that is responsibilized, active, prudent, enterprising; in a word, autonomous. It follows that educational systems have been reconfigured so that the demands of the educational "field" and the corresponding "educational capital" with which it endows students [21,40,42] are aligned with the demands of active, lean citizenship.

With the broader trends outlined and the concepts of discipline and governance articulated, we can now turn to the implications that these themes have had for the institution of education as a site and mechanism of governance. Exploring the transformations in education further develops an analytic framework with which to understand reformations in education policies.

\subsection{Implications for Education}

“No policy area exists in a vaccum,” as Stephen McBride [43] (p. 159) suggests, and thus all fields are "bound to be conditioned by the overall economic paradigm that shapes economic and social policy generally.” Today, education is increasingly understood along the lines drawn by Gary Becker [44] in his seminal work Human Capital. According to this conceptualization, education is an activity that increases one's resources within - that is, intangible entities-which is known as investing in "human capital" [44] (p. 1). As such, education is crucial to the economy in that it is in the business of "the production of training” [44] (p. 29). In critiquing Becker's theory, Gillies [45] (p. 225) describes it as a "simple equation" which reads, "the more and better education that individuals possess, the better their returns in financial rewards and the better the national economy flourishes." All this is supported by the fact that "abler persons" (determined by aptitude tests) are found to earn more because they invest more in education [44] (p. 79). The human capital-inspired understanding of education is characteristic of the neoliberal context in which the institution is situated and operates. As Carroll and Beaton [46] note, higher education fits neatly within neoliberal regimes, as the institution's key activities of research and skills development are availed as resources for national economic development (see also [47,48]). In turn, higher education has been identified as a site for "profit-making” at the individual, business, and national levels [46] (p. 72).

It is important to note also that Becker sees a link between criminality and educational training through his economic lens: "a rise in the income available in legal activities or an increase in law-abidingness due, say, to 'education' would reduce the incentive to enter illegal activities and would reduce the number of offenses" [49] (pp. 10-11). In this way, education is conceptualized as operating as a "control" of sorts. That is, education, as a "legitimate" means of pursuing "legitimate" goals, comes to hold value for its perceived capacity to prevent individuals from economic dependency, and in turn, criminality. 
The institution of education, as an institution for governance, has changed in part because of the influence of human capitalist thought among policy makers $[43,45]$. To be sure, I do not claim that the idea of schools operating as sites of governance is at all new. The school, from its inception, has been central to social ordering and governance in capitalist societies (see especially, [50-53]). What is new, though, is that human capital theory-inspired policymaking has brought about systems of education that are characteristically neoliberal, reorienting the institution to play a central role in strategies that have been conceptualized in the literature according to two separate but related theses: the "criminalization of schools" thesis and the "neoliberalization" or "marketization of education" thesis. The criminalization of schools points to the increased duty or role schools have in governing crime in and around schools, which is seen in the disregarding of children's rights on the grounds that strategies such as surveillance technologies, armed guards, and lock-down drills keep children safe [54-56]. Not only do schools govern crime, they are "governed through crime", as Jonathan Simon [57] suggests that crime is now central to the school's symbolic gateway to citizenship in contemporary society.

The governance of education through crime means that schools have developed a "penal pedagogy"the borrowing and adopting of practices from criminal justice, illustrated by student uniforms, zero tolerance policies, and in-school detention [57] (pp. 220-221; see also [58]). On top of these practices, more behaviors which previously escaped school responses are becoming subject to disciplinary procedures. That is, schools under the new penal pedagogy are "defining deviance up" [57] (p. 224). This is connected to Garland's [13] (pp. 456-457) observation that states are increasingly defining deviance down, allowing minor offences and offenders to "slip" through the crime control "net" that is "in danger of bursting" as a result of coming to grips with the "myth of the sovereign state". By defining deviance up within schools, a new net of sorts is formed on which problems dodged by crime control agencies can fall, with education taking up the slack left by the criminal justice system. In other words, education is aligned with the "criminal process" [59].

Alongside the criminalization of schools operates a separate (but related), more subtle and indirect mode of governance, one organized around a concern for markets. As Michael Peters [60] suggests, education policies are shaped generally in line with the shift in social regulation towards neoliberalism, creating a "new prudentialism in education" that promotes the enterprising self and the idea of education as an investment. This alludes to the notion of "market discipline” [24], through which students learn to turn to markets for solutions to their problems. In a lean state, schooling aims to teach students "how to realize themselves through the market" by making themselves "marketable" and meeting their needs by navigating through the market [61] (p. 78, my emphasis). Treating education as an investment disciplines individuals according to neoliberal principles of responsibilization for personal welfare and managing economic (in)security. As Frauley [21] (p. 221, drawing on Spitzer) suggests concerning higher education in Ontario, the concept of "employability" has been used to construct policies as regulatory strategies through its capacity to promote "security effects".

These developments have made possible (and reinforce) the advancement of the notion of the "new vocationalism" in education, that is, the reorientation of the education system to focus on labor market preparation in a lean state [60,61]. The new vocationalism reorganizes schooling to concern "labor discipline”, through which students learn work habits and to align personal life goals with employers' needs [61]. Although this seems to make reference to the original premise of the introduction of mass education to meet the skills demands of industrialization, Sears [61] suggests that a lean education 
concerns the cultivation of particular attitudes rather than skills. Rather than being driven by specific skills training and an inclusive political project of social harmonization (as with [pre-]welfare state education), the new vocationalism is concerned with measuring student performance so as to align occupational expectations with the labor market and new forms of "subjectivity and discipline required for an increasingly polarized society” [61] (p. 68). Thus, Sears [61] (p. 73) suggests the institution is oriented toward "the development of new subjectivities more closely attuned to the requirements of the labour market."

\section{Ontario’s Reconfiguring of Education through "Bullying”}

At this point, I turn to education reformations that have occurred in the Canadian province of Ontario in order to explore empirically education's criminological relevance. This section is intended to illustrate the utilization of the analytic framework I have outlined above, and not as an exhaustive discussion of the policy documents. Drawing on research I have conducted, it is hoped to exemplify one way criminology offers a novel lens through which to view education, and how education as a field of inquiry can shed more light on criminological interests.

\subsection{Student Discipline and Community Safety}

In 2004, the Ontario Ministry of Education and the Ministry of Community Safety and Correctional Services initiated an inquiry into the safety conditions inside Ontario schools, establishing the Safe Schools Action Team. Composed of experts in education and safety, the Action Team's task was to review the former Progressive Conservative government's Safe Schools Act. The Liberal government approached school safety by targeting the previous Conservative government's "zero tolerance" approach, challenging the usage of suspensions and expulsions in favor of a preventive strategy. The emphasis on suspending and expelling students was also perceived to be a threat to the entire community's safety, as it was believed that suspended and expelled students had nothing to do with "few productive alternatives to school" [62] (p. 14, my emphasis), thus implying that those students are positioned as suspicious and dangerous. As Minister of Education Hon. Kathleen Wynne argued, mandatory programs for these students to earn their way back into the classroom would operate in the best interests of the child, "but surely, [also] in the best interests of all of us in society, because we need each of those students to reach his or her potential. That will never happen as long as kids are relegated to the mall or relegated to the streets because we have not provided opportunities for those students” [63] (see also Marchese and Delaney in [64]; Bisson in [65]).

The Action Team's "safety audit” found that bullying behavior was a significant problem facing students, marking the apparent "discovery of bullying”, and leading to the passage of Bill 212 and Bill 13 later on. Rather than a "true” discovery, I suggest bullying was a discursive reality produced via information gathering mechanisms such as the provincial safety audit and "School Climate Surveys” to be completed by students, teachers and parents every two years [66,67]. Bullying, then, was understood as the main impediment on safety inside and outside schools, as it was seen to be the reason behind suspensions and expulsions, thus "kicking kids onto the streets" and interrupting some students' academic success. This resulted in two important categories: the bully and the victim, which both have as their status "threats" to safety. These referred to separate but interrelated categories of 
student, both conceptualized as problem populations. Safety inside schools was tied directly to public safety through these figures. The bully was seen as the community's future criminal/deviant. As well, the bully posed a threat inside schools in that their behavior damaged children by producing victimized youth. In turn, the victim was also problematic in that the trauma they suffered would jeopardize their future economic productivity [68] (p. 10); [69] (p. 1487); [70] (p. 1652); [71] (p. 1829); [72] (p. 4).

The overarching recommendation from the Action Team was the bullying prevention should be a priority for all school boards and schools [68] (p. 6), establishing the basis for the shift in thinking about school safety. Emphasis ought to be placed on preventing certain behaviors (but encouraging others) among students, thus rendering school safety, and consequently community safety, a matter of student discipline. Indeed, it was considered "fundamentally wrong that we simply suspend or expel students and leave them without the supports they need ... to transition back into [the] classroom and become the best they can possibly be" [63]. Thus, the appropriate course of action would mean rethinking disciplinary practices in order to cultivate ideal subjects in Ontario schools instead of simply eliminating problems from the school level via suspension or expulsion. Consider Liberal MPP Bob Delaney's comment:

What difference is a safe school going to make? It's going to keep kids in school. If you keep kids in school, then you go a big step toward addressing one of the real problems not only in this country but in every country, and that is that more than four out of five inmates in Canada’s prison population are people who never completed high school [64].

This linking of lack of education and criminality points to the logic suggesting that mandatory education plays a crucial role in managing problems not only inside schools, but also outside of them. As he further noted: “We don’t want to chase you out; we want to chase you in” [64].

The move away from a zero-tolerance approach to student discipline was encapsulated in the concept of "progressive discipline". Progressive discipline, according to the Ontario Ministry of Education, is an approach to student discipline that promotes positive behavior and ensures appropriate consequences in the case of inappropriate behavior [73]. Under a progressive discipline regime, bullying is added as an infraction for which suspension must be considered; mandatory suspensions and expulsions are replaced (except in limited circumstances) by requiring principals to consider all factors in specific cases, and suspended/expelled students are offered more opportunities to continue learning and "help them get back on track" [73].

This concept of "progressive discipline” operates along the lines of Foucault's conception of discipline as a positive modality of power. Indeed, as Minister of Education Kathleen Wynne put it, the progressive disciplinary regime was a "positive" approach to discipline, distinguishable from one with a "negative view of our students," in that it is "rooted in a strong liberal—and that is small-l and capital-L Liberal-belief in human potential” [74]. The processes traced by Foucault, of hierarchical observation (or, surveillance) and normalizing judgment (or, normalization) were deployed as a means of constituting particular subjects.

Ontario's progressive disciplinary regime could produce and classify students as "bullies", "victims" and/or "witnesses", and as such, subject them to programming that would (re)align their conduct with normative expectations as set out in the field of education. This was an instance of what Foucault would term "correcting” student subjects according to a "norm". As the bully and the victim 
were categories of student deemed undesirable for various reasons, both figures began to constitute a norm of behavior by clearly setting out what was not expected of students. The categorizing of students as bullies or victims made up the "negative pole" of the distribution of behaviors [38] (p. 180). Though "progressive discipline" was thought to eliminate an exclusionary discipline regime (as in the Conservatives' customary use of student suspension and expulsion), the implementation of special programming for bullies and victims effectively functioned as an exclusionary process of discipline to exercise over students "a constant pressure to conform to the same model ... [s]o that they might all be like one another" [38] (p. 182). In the discussion below, by analyzing the preventive strategy that would operate alongside progressive discipline, we get a sense of the "model” student-subject (i.e., the "positive pole”) that Ontario education policies sought to produce and how.

\subsection{The Prevention of Bullying}

Progressive discipline, though it responded to bullying in a way that aimed to prevent those involved from bullying again, did not address a third key figure to the bullying matter: the bystander or witness of bullying. The progressive discipline regime included programming for witnesses of bullying, similar to what we have seen with the bully and the victim. Essentially, this meant that all students were considered to be involved with and contributing to the bullying problem, either directly or indirectly. As Hon. Laurel Broten suggested, “there are no good guys and bad guys; today's bully can be tomorrow's bullied, and a bystander the day after that” [75] (p. 407, my emphasis). This was largely because bullying was understood as "a learned behaviour" that has long-lasting effects on all who experience it: "It is a cyclical problem, and if not addressed in childhood, it will burden our medical, policing and social service programs with hurt and hurting adults. Simply put, bullying costs time, money and literally lives” [76] (p. 80).

With progressive discipline managing the dangers posed by the bully and the victim, the notion of witnesses learning bullying behavior required that the disciplinary project be extended to involve a bullying prevention strategy pertaining to all school actors. This involved the creation of a sort of pedagogy of bullying, with the aim of transforming the everyday practices of schooling to develop a "prevention-oriented education”. As a result, I suggest, surveillance over students was expanded not only because more students would be subjected to a "disciplinary-normalizing gaze” [38], but because students would now subject the gaze as well. The bullying prevention strategy developed by the Ministry of Education put forward a norm of conduct around which students were "judged". The various prevention techniques sought to responsibilize students for their personal well-being by enhancing their ability to self-regulate, which also meant actively regulating their peers' behavior. Bullying made it possible, then, to add yet another process of examination to the "apparatus of uninterrupted examination” that Foucault [38] (p. 186) saw in the school. That is, students would be perpetually subject to examination surrounding their conduct in reference to bullying, which would make it "possible to qualify, to classify, and to punish" [38] (p. 184).

Character development, encompassing academic achievement, respect for diversity, citizenship development, and parent and community partnerships, then became a central component to education:

A quality education is not only geared towards the intellect, but also towards attitudes, behaviours, dispositions and sensibilities. It emphasizes all aspects of the self and domains 
of learning - the cognitive, affective, attitudinal, and behavioural. Character development, which encompasses all these domains, is a fundamental goal of education in Ontario [77] (p. 10, my emphasis).

Thus, schooling was conceptualized in a way that varied from an orientation entirely towards academics or intellectual curiosity. Preparation for the workplace was sought through character development, as the Ministry emphasized essential skills and work habits that are pertinent to "virtually all occupations” (e.g., reliability, responsibility, integrity, initiative, and respect) [77] (p. 10, 12). More benign attributes such as "honesty" and "respect for diversity” were also tied directly to labor market integration, as they were conceived as "personal management skills ... essential for students entering the workplace” [77] (p. 10). Through character development, it was argued, students are provided with "tools" or "skills" (which are in fact attitudes or dispositions) that will influence positive outcomes in their lives. This resonates with Sears' [61] argument that education in the lean state is less about skills development and more concerned with cultivating attitudes aligned with labor market needs. These "skills" would empower students to "function effectively in our diverse society and in our global economy" which "individuals and society need in order to achieve excellence in all facets of life" [77] (p. 17).

Character development was tied closely to the notion of citizenship development, which put forward a conception of citizenship as a right contingent upon the fulfillment of responsibilities. Ontario schools focused on community responsibilities, celebrating "service learning" and the forty hours of community service students must complete in order to graduate from secondary school [77] (p. 22; see also [61]). A novel development pertaining to citizenship/character development and community-building has emerged from the bullying prevention initiative. Increased responsibility for personal and community well-being was also applied in approaching the immediate safety conditions of schools and communities. Since education was argued to be so crucial to the safety of future communities, schools needed to be made safe immediately, as we have seen that no learning could reasonably occur without the sense of "safety". As bullying behavior was seen as the primary threat to student safety, bullying needed to be eliminated from the school environment. Impeding students' capacities to learn, bullying not only hurt some students' academic success, but was also seen as counteractive to character and citizenship development. According to Liz Sandals, stakeholders saw "prevention strategies" as important to “deter inappropriate behaviours and help all students make sound personal decisions" [63] (my emphasis). The prevention of bullying, then, became a key element of education in Ontario, constituting the ideal student as one who takes responsibility to actively manage the school community's safety as well as one's personal well-being. In this way, students would be "responsibilized" [14].

A component of character development, bullying prevention, and consequently student safety, became a responsibility of students. Bullying prevention and the establishment of a safe school community thus required developing a competence within each student to prevent problematic behavior, which meant controlling their own behavior and that of their peers. Importantly, this capacity was conceptualized as the result of students being extensively skilled. (One Ministry document lists up to 27 specific skills under four general categories-recognize bullying, report incidents confidently, respond to incidents safely, prevent bullying from happening —as outcomes for students learning from a prevention-oriented education [68]). Like service learning, bullying prevention was also presented as a program that provides students with “tools” and "skills” valuable for adult life as responsible citizens. 
One of the many "skills" involved in taking responsibility over bullying was the ability to "join groups and make friends". The promotion of this skill was pursued directly through Bill 13 in its focus on positive and healthy relationships. As Minister of Education Laurel Broten suggested, Ontario education had done much work in the "three Rs" of schooling (i.e., reading, writing and arithmetic), but more work was needed "with respect to the fourth R, that of relationships" [75] (p. 411). It was argued that more funding was needed for anti-bullying programs, and that we consider "the lack of social-skill-building opportunities in a curriculum that has become increasingly focused on narrow EQAO results" [78] (p. 1457, my emphasis). This effort to "rationalize childhood", paraphrasing Sears [61], through empowering students by way of "social-skilling" is a reflection of the "enterprise education” [79] that is aligned with the “enterprise culture's” values of independence and self-reliance.

\subsection{Bullying, Regulation, and Education as Governance}

"The norm is something that can be applied to both a body one wishes to discipline and a population one wishes to regularize" [80] (p. 253). Following this, we can think of the interconnection forged by the Ontario Ministry of Education and Ontario policymakers between progressive discipline, character/citizenship development, and bullying prevention as formulating both a disciplinary project as well as a governmental project. That is, the matter of "bullying" was set up as a "regulatory project” [81] (p. 320) or “programme of government” [29] (p. 181).

Thus, in what follows, I demonstrate the way these developments in student discipline reconfigure the educational field to operate as a mechanism of governance in contemporary neoliberal society, along the lines Foucault [36] traced as a "security apparatus". I suggest that education policy concerns public safety and security in that educational capital, in its most basic (but necessary) form, makes successful integration into other markets possible. That is, because secondary education is understood as fundamental to securing paid employment in a capitalist society, those lacking basic educational capital are considered, at best, an economic burden on society, or at worst, a criminal danger to the public. However, the reformation was not simply a matter of credentialing more students; rather, the form and content of education also needed to be rethought. The progressive disciplinary regime and bullying prevention strategy, as a regulatory project, concerns the "educational capital” [21,42] students acquire. The reorganization of the disciplinary regime in Ontario schools, which overlaps significantly with the curriculum and educational experience, aims at better controlling behavior and preventing misbehavior well beyond the school career.

By keeping youth in school and thus credentialing more students with an education that is responsive to the needs of individuals, workplaces, and communities, education policy reformations in Ontario demonstrate a concern for protecting the public from the insecurity associated with unemployment, inactivity, and a lacking capacity to regulate oneself. It was thought that this disciplinary and regulatory project surrounding bullying in schools attached to basic educational capital an enhanced autonomy for students, which would facilitate this population's integration within society. In this way, education policies were deployed in a way to operate more according to a public safety rationality, concerned with governing social (in)security and public tranquility.

The discussion above suggests that schooling was seen as involved in what Spitzer [82] terms "problem populations" that pose a threat to capitalist social relations of production. The institution of 
education has been reoriented to control and regulate students as a "problem population" posing a threat as "social junk" [82] (p. 645), as anti-social behavior, specifically in the form of bullying, was thought to produce damaged subjects (i.e., bullies and victims) that fail to participate in productive roles. Rather than treating the bullying problem as a "passive" threat requiring mere "containment," the regulatory project put into place "preventive-integrative” controls [82] (p. 648). Such a regulatory project sought to produce autonomous subjects, which would govern social insecurity in a distinctively neoliberal way.

This aim to produce autonomous subjects involved a human capital-influenced conception of education among policymakers. Throughout the debates surrounding Bill 212 and Bill 13, members of parliament and stakeholders expressed concern over the future prosperity of the province of Ontario as a result of the (perceived) increasing failure of the education system to produce the sort of graduates prepared for citizenship and life in contemporary (neoliberal) society (i.e., market dependence). Security was thus conceptualized in terms of individual economic productivity and sufficiency, which would in turn promise social security and order. Education was understood as a crucial element in making individuals economically self-sufficient, as illustrated in the legislation's concern with enhancing the safety preconditions for academic excellence which is thought to ensure successful integration into markets. As the Safe Schools Action Team put it, creating a safe school environment would permit the Ontario government to achieve its objective of ensuring its schools "prepare all students for success in their destination of choice, whether a work placement, apprenticeship, college or university” [83] (p. 4). Acquisition of basic educational capital, then, would necessarily lead to successful market integration, and thus this disciplinary-regulatory project serves to extend "market discipline" [24,61].

The orientation of education towards the market is served by a vocationalist view of education [61] (p. 78). Progressive discipline and the bullying prevention strategy can be regarded as operating along these lines. Progressive discipline mandates alternative programming for responding to misbehavior, which involves career counseling and volunteer "opportunities", to help those students "get back on track". As well, and perhaps more importantly, the "pedagogy of bullying”, with its lessons of character/citizenship development, was promoted as providing all students with skills (as in "social skills”) for future employment necessary to succeed in a global economy. In this way, students are subjected to labor discipline, as schooling is increasingly concerned with developing competencies which are defined as desirable by employers [61] (p. 79). Despite the human capital-influenced rhetoric surrounding policy reformations, education does not simply provide skills training; rather, education aims to form within students a "lean ethos" [61] (p. 81). This is the "cultural side" of the lean disciplinary regime, elaborated by Sears, which seeks to cultivate particular attitudes. Thus, we can take the project of regulation surrounding bullying in Ontario as part of the "new vocationalism" developing “new subjectivities” aligned with market demands [61] (p. 73).

Although Bill 212 and Bill 13 were constructed in a way to reorient the educational field to operate as a mechanism for governing social insecurity by way of transitioning students from school into markets (i.e., labor, higher education, consumer), these policies also have a certain link to crime control. This link was drawn by making the simple, human capitalist argument that if more individuals received an education (in this equation, operating as a "control”), crime would be diminished. But the regulatory project that I am concerned with goes beyond the mere credentialing of more youths: it 
concerns the disciplining of students according to the norms of social, economic, and political life in contemporary neoliberal society in order to regulate and govern a population of autonomous subjects. And in this regard, the disciplinary-regulatory project of bullying in Ontario education may be considered what Garland [14] (pp. 113-127) terms an "adaptive strategy of responsibilization”. That is, the education field was not only aligned with labor market demands, but also with practices of crime control.

Indeed, from the very outset of the legislation, in announcing the establishment of the Safe Schools Action Team to examine school safety, the Ministry of Education was engaged in a collaborative effort with the Ministry of Community Safety and Correctional Services. Collaborating with an official state agency of criminal justice for rethinking school practices reflects what Simon [57] (p. 216) sees as "the triumph of crime over other agendas for reimagining schools." Simon [57] points to the way schools "define deviance up" in a way that reorients the governance of education to deal with problems of which the criminal justice system has absolved itself by "defining deviance down" [14]. From the policies, "bullying”, which Simon [57] briefly touches on, came to be defined as deviance requiring a response (as a new infringement under the provincial Code of Conduct), in effect “defining deviance up”. No longer was bullying to be considered, as it had been, a regular "part of growing up” [68] (p. 11); [72] (p. 3).

In promoting the individualization of responsibility concerning matters of personal safety and well-being, the logics of enterprise and prudentialism, and the importance of community and partnering [24-28,31,34,60], the educational field can be seen to operate as part of a "biopolitical" [35,80] project to produce and regulate a population of lean, active citizens that can integrate within society by way of smoothly making the transition from the school into other markets. Furthermore, the policy reformations made schooling a relevant mechanism for instilling an ethos conducive to the adaptive strategy, responsibilizing students and other school actors for managing their personal security. Thus, in this biopolitical project we can see a concern for integrating student populations by way of configuring the demands of one field (i.e., education) to correspond with the demands of others (i.e., labor markets, crime control).

\section{Conclusions}

What I have tried to do in this paper is offer an idea of what a critical criminology of education might entail. That is to say, in adopting the insights of some critical criminologists in regard to the analytic strength of a governance framework [13,14,17-20], I have given some thought to the way a critical criminology of education that takes an "education as governance" [21] approach may proceed. In so doing, I have brought some attention to only some criminologically relevant developments in one particular educational field. Importantly, this sort of endeavor might be considered one component of an imaginative criminological enterprise. The paper has suggested both the analytic strength and imaginative capacity of the governance approach for criminological inquiry by way of its employment in developing a criminological account of Ontario's educational reformation concerning student discipline policies. An analytic framework indebted to criminological, socio-legal, political sociological, and educational research, such as the one outlined in this paper, for studying educational policies, practices and the like can be used to develop novel descriptions and 
understandings not only of educational systems, but also provide further insight into the ways neoliberal societies are governed.

The framework, as I have illustrated, enables me to argue that Ontario's recent education reformations as they pertain to student discipline further configure the institution to operate as a security apparatus concerned with the management of (potential) problem student populations and ensuring public safety. Thus, it makes possible the criminological study of education that does not prioritize the domain of criminal justice. However, taking education to be a central institution of governance does not necessarily preclude any relevance to the criminal justice system - the aim is not to eliminate crime and criminal justice from the criminological enterprise, but to decenter them (see the correspondence between [10] and [84]). A focus on governance and ordering may shed light on crime and criminal justice in that it allows one to attend to institutions that are aligned with modes of state crime control, which I alluded to in my theoretical discussion on the "progressive discipline” regime. But, on top of contributing to understandings of the "criminal process", such a critical criminology can also help us gain valuable knowledge pertaining to other topics of interest for criminologists, such as regulation, security, social ordering, and so on.

\section{Conflicts of Interest}

The author declares no conflict of interest.

\section{References and Notes}

1. Cohen, A. Delinquent Boys: The Culture of the Gang; The Free Press: New York, NY, USA, 1955.

2. Gottfredson, D. Schools and Delinquency; Cambridge University Press: New York, NY, USA, 2001.

3. Gottfredson, G.; Gottfredson, D.; Payne, A.; Gottfredson, N. Predictors of school disorder: Results from a national study of delinquency prevention in schools. J. Res. Crime Delinq. 2005, 42, 412-444.

4. Welsh, W.; Greene, J.; Jenkins, P. School disorder: The influence of individual, institutional, and community factors. Criminology 1999, 37, 73-116.

5. Behan, C. Context, creativity and critical reflection: Education in correctional institutions. J. Correct. Educ. 2007, 58, 157-169.

6. Piché, J. (Ed.) Education in Prisons; Special Issue of Journal of Prisoners on Prisons; University of Ottawa Press: Ottawa, ON, Canada, 2008; Volume 17, pp. 1-130.

7. Duguid, S. Rehabilitation through education: A Canadian model. J. Offender Couns. Serv. Rehabil. 1982, 6, 53-67.

8. Linden, R.; Perry, L. The effectiveness of prison education programs. J. Offender Couns. Serv. Rehabil. 1982, 6, 43-57.

9. Braithwaite, J. The new regulatory state and the transformation of criminology. Br. J. Criminol. 2000, 40, 222-238.

10. Shearing, C. Decriminalizing criminology: Reflections on the literal and tropological meaning of the term. Can. J. Criminol. 1989, 31, 169-178. 
11. Valverde, M. Beyond Discipline and Punish: Foucault's challenge to criminology. Carcer. Noteb. 2009, 4, 201-224.

12. Ericson, R. Making criminology. Curr. Issues Crim. Justice 1996, 8, 14-25.

13. Garland, D. The limits of the sovereign state: Strategies of crime control in contemporary society. Br. J. Criminol. 1996, 36, 445-471.

14. Garland, D. The Culture of Control: Crime and Social Order in Contemporary Society; University of Chicago Press: Chicago, IL, USA, 2001.

15. Rose, N. Government and control. Br. J. Criminol. 2000, 40, 321-339.

16. Shearing, C. Reinventing policing: Policing as governance. In Policing Change, Changing Police: International Perspectives; Marenin, O., Ed.; Garland Publishing: New York, NY, USA, 1996; pp. 285-305.

17. Garland, D. 'Governmentality' and the problem of crime: Foucault, criminology, sociology. Theor. Criminol. 1997, 1, 173-214.

18. Feeley, M.; Simon, J. The new penology: Notes on the emerging strategy of correction and its implications. Criminology 1992, 30, 449-474.

19. Feeley, M.; Simon, J. Actuarial justice: The emerging new criminal law. In The Futures of Criminology; Nelken, D., Ed.; SAGE: London, UK, 1994.

20. Simon, J.; Feeley, M. The form and limits of the new penology. In Punishment and Social Control, 2nd ed.; Blomberg, T., Cohen, S., Eds.; Aldine de Gruyter: Hawthorne, NY, USA, 2003.

21. Frauley, J. Post-social politics, employability, and the security effects of higher education. J. Pedag. 2012, 3, 219-241.

22. Rice, J.; Prince, M. Changing Politics of Canadian Social Policy; University of Toronto Press: Toronto, Canada, 2000.

23. Teeple, G. Globalization and the Decline of Social Reform; Garamond Press: Toronto, Canada, 1995.

24. Sears, A. The "lean" state and capitalist restructuring: Towards a theoretical account. Stud. Polit. Econ. 1999, 59, 91-114.

25. Walters, W. The 'Active Society': New designs for social policy. Policy Polit. 1997, 25, 221-234.

26. O’Malley, P. Post-social criminologies: Some implications of current political trends for criminological theory and practice. Curr. Issues Crim. Justice 1996, 8, 26-38.

27. Larner, W. Neoliberalism: Policy, ideology, governmentality. Stud. Polit. Econ. 2000, 63, 5-25.

28. Rose, N. The death of the social?: Re-figuring the territory of government. Econ. Soc. 1996, 25, 327-356.

29. Rose, N.; Miller, P. Political power beyond the State: Problematics of government. Br. J. Sociol. 1992, 43, 173-205.

30. Bauman, Z. Community: Seeking Safety in an Insecure World; Polity Press: Cambridge, UK, 2001.

31. O’Malley, P. Risk and responsibility. In Foucault and Political Reason: Liberalism, Neo-liberalism, and Rationalities of Government; Barry, A., Osborne, T., Rose, N., Eds.; University of Chicago Press: Chicago, IL, USA, 1996; pp. 189-207.

32. Rose, N. Governing the enterprising self. In The Values of the Enterprise Culture: The Moral Debate; Heelas, P., Morris, P., Eds.; Routledge: New York, NY, USA, 1992; pp. 141-164.

33. Heelas, P. Reforming the self: Enterprise and the characters of Thatcherism. In Enterprise Culture; Keat, R., Abercrombie, N., Eds.; Routledge: New York, NY, USA, 1991; pp. 72-90. 
34. Cruikshank, B. Revolutions within: Self-government and self-esteem. Econ. Soc. 1993, 22, 327-344.

35. Foucault, M. The History of Sexuality, Vol. 1: An Introduction; Hurley, R., Trans.; Vintage: New York, NY, USA, 1990.

36. Foucault, M. Governmentality. In The Foucault Effect: Studies in Governmentality; Burchell, G., Gordon, C., Miller, P., Eds.; University of Chicago Press: Chicago, IL, USA, 1991; pp. 87-104.

37. Foucault, M. The subject and power. Crit. Inq. 1982, 8, 777-795.

38. Foucault, M. Discipline and Punish: The Birth of the Prison; Sheridan, A., Trans.; Vintage: New York, NY, USA, 1979.

39. Swartz, D. Forms of power in Bourdieu's sociology. In Symbolic Power, Politics, and Intellectuals; University of Chicago Press: Chicago, IL, USA, 2013; pp. 30-46.

40. Bourdieu, P. The social space and the genesis of groups. Theo. Soc. 1985, 14, 723-744.

41. Bourdieu, P. Structures, Habitus, Practices. In The Logic of Practice; Nice, R., Trans.; Stanford University Press: Stanford, CA, USA, 1990; pp. 52-65.

42. Bourdieu, P. The forms of capital. In Handbook of Theory and Research for the Sociology of Education; Richardson, J., Ed.; Greenwood Press: New York, NY, USA, 1986; pp. 241-258.

43. McBride, S. Policy from what?: Neoliberal and human-capital theoretical foundations of recent Canadian labour-market policy. In Restructuring and Resistance: Canadian Public Policy in an Age of Global Capitalism; Burke, M., Mooers, C., Shields, J., Eds.; Fernwood Publishing: Halifax, Canada, 2000; pp. 159-177.

44. Becker, G. Human Capital: A Theoretical and Empirical Analysis, with Special Reference to Education; National Bureau of Economic Research; Columbia University Press: New York, NY, USA, 1964.

45. Gillies, D. State education and high-yield investment: Human capital theory in European policy discourse. J. Pedagogy 2011, 2, 224-245.

46. Carroll, W.; Beaton, J. Globalization, neo-liberalism, and the changing face of corporate hegemony in higher education. Stud. Polit. Econ. 2000, 62, 71-98.

47. Miller, T. Governmentality or commodification?: US higher education. Cult. Stud. 2003, 17, 897-904.

48. Rhoades, G.; Slaughter, S. Academic capitalism, managed professionals, and supply side higher education. Soc. Text 1997, 15, 9-38.

49. Becker, G. Crime and punishment: An economic approach. In Essays in the Economics of Crime and Punishment; Becker, G., Landes, W., Eds.; National Bureau of Economic Research; Columbia University Press: New York, NY, USA, 1974; pp. 1-54.

50. Bowles, S.; Gintis, H. Schooling in Capitalist America: Educational Reform and the Contradictions of Economic Life; Basic Books: New York, NY, USA, 1976.

51. Curtis, B. True Government by Choice Men?: Inspection, Education, and State Formation in Canada West; University of Toronto Press: Toronto, Canada, 1992.

52. Kirk, D. Schooling Bodies: School Practice and Public Discourse, 1880-1950; Leicester University Press: London, UK, 1998. 
53. Spring, J. Education as a form of social control. In Roots of Crisis: American Education in the Twentieth Century; Karier, C., Violas, P., Spring, J., Eds.; Rand McNally College Publishing Company: Chicago, IL, USA, 1973; pp. 30-39.

54. Giroux, H. Against the Terror of Neoliberalism: Politics Beyond the Age of Greed; Paradigm Publishers: Boulder, CO, USA, 2008.

55. Hirschfield, P. Preparing for prison?: The criminalization of school discipline in the USA. Theor. Criminol. 2008, 12, 79-101.

56. Robbins, C. Expelling Hope: The Assault on Youth and the Militarization of Schooling; State University of New York Press: Albany, NY, USA, 2008.

57. Simon, J. Governing Through Crime: How the War on Crime Transformed American Democracy and Created a Culture of Fear; Oxford University Press: New York, NY, USA, 2007.

58. Raby, R. Polite, well-dressed and on time: Secondary school conduct codes and the production of docile citizens. Can. Rev. Soc. Anthrop. 2005, 42, 71-92.

59. Wells, C.; Quick, O. Lacey, Wells and Quick: Reconstructing Criminal Law, 4th ed.; Cambridge University Press: Cambridge, UK, 2010.

60. Peters, M. The new prudentialism in education: Actuarial rationality and the entrepreneurial self. Educ. Theory 2005, 55, 123-137.

61. Sears, A. Retooling the Mind Factory: Education in a Lean State; Garamond: Aurora, Canada, 2003.

62. Ontario Ministry of Education. Safer Schools... Safer Communities: Discussion Guide; Queen’s Printer for Ontario: Toronto, Canada, 2005.

63. Ontario. Hansard; 38th Legislature, 2nd Session; Legislative Assembly of Ontario: Toronto, Canada, 25 April 2007. Available online: http:/www.ontla.on.ca/house-proceedings/transcripts/ files_html/25-APR-2007_L163A.htm\#PARA541 (accessed on 1 March 2015).

64. Ontario. Hansard; 38th Legislature, 2nd Session; Legislative Assembly of Ontario: Toronto, Canada, 26 April 2007. Available online: http:/www.ontla.on.ca/house-proceedings/transcripts/ files_html/26-APR-2007_L164.htm\#PARA773 (accessed on 1 March 2015).

65. Ontario. Hansard; 38th Legislature, 2nd Session; Legislative Assembly of Ontario: Toronto, Canada, 30 April 2007. Available online: http:/www.ontla.on.ca/house-proceedings/transcripts/ files_html/30-APR-2007_L165B.htm\#PARA29 (accessed on 1 March 2015).

66. Ontario. Bill 13, An Act to Amend the Education Act with Respect to Bullying and other Matters, S.O. 2012, C. 5; Legislative Assembly of Ontario: Toronto, Canada, 2012. Available online: http://ontla.on.ca/web/bills/bills_detail.do?locale=en\&BillID=2549 (accessed on 1 March 2015).

67. Ontario Ministry of Education. School Climate Survey: A Survey for Students in Grades 7-12... (Sample); Queen's Printer for Ontario: Toronto, Canada, 2009.

68. Ontario Ministry of Education. Shaping Safer Schools: A Bullying Prevention Action Plan; Queen’s Printer for Ontario: Toronto, Canada, 2005.

69. Ontario. Hansard; 40th Parliament, 1st Session; Legislative Assembly of Ontario: Toronto, Canada, 4 April 2012.

70. Ontario. Hansard; 40th Parliament, 1st Session; Legislative Assembly of Ontario: Toronto, Canada, 18 April 2012.

71. Ontario. Hansard; 40th Parliament, 1st Session; Legislative Assembly of Ontario: Toronto, Canada, 25 April 2012. 
72. Ontario Ministry of Education. Bullying: We Can all Help Stop It; Queen's Printer for Ontario: Toronto, Canada, 2013.

73. Ontario Ministry of Education. Progressive Discipline: A New Approach to Make Schools Safer; Queen's Printer for Ontario: Toronto, Canada, 2008.

74. Ontario. Hansard; 38th Legislature, 2nd Session; Legislative Assembly of Ontario: Toronto, Canada, 4 June 2007. Available online: http:/www.ontla.on.ca/house-proceedings/transcripts/ files_html/04-JUN-2007_L181A.htm\#PARA581 (accessed on 1 March 2015).

75. Ontario. Hansard; 40th Parliament, 1st Session; Legislative Assembly of Ontario: Toronto, Canada, 11 December 2011.

76. Ontario. Hansard; 40th Parliament, 1st Session, Standing Committee on Social Policy (Accepting Schools Act, 2012); Legislative Assembly of Ontario: Toronto, Canada, 2012.

77. Ontario Ministry of Education. Finding Common Ground: Character Development in Ontario Schools, K-12; Queen's Printer for Ontario: Toronto, Canada, 2008.

78. Ontario. Hansard; 40th Parliament, 1st Session; Legislative Assembly of Ontario: Toronto, Canada, 3 April 2012.

79. Peters, M. Education, enterprise culture and the entrepreneurial self: A Foucauldian perspective. J. Educ. Enq. 2001, 2, 58-71.

80. Foucault, M. Lecture 11: 17 March 1976. In "Society Must Be Defended”: Lectures at the Collège de France, 1975-1976; Macey, D., Trans.; Picador: New York, NY, USA, 2003; pp. 239-264.

81. Hunt, A. Explorations in Law and Society: Towards a Constitutive Theory of Law; Routledge: New York, NY, USA, 1993.

82. Spitzer, S. Toward a Marxian theory of deviance. Soc. Probl. 1975, 22, 638-651.

83. Ontario Ministry of Education. Safe Schools Policy and Practice: An Agenda for Action; Queen's Printer for Ontario: Toronto, Canada, 2006.

84. Hunt, A. Criminology: What's in a name? A response to Clifford Shearing. Can. J. Criminol. 1990, 32, 657-658.

(C) 2015 by the author; licensee MDPI, Basel, Switzerland. This article is an open access article distributed under the terms and conditions of the Creative Commons Attribution license (http://creativecommons.org/licenses/by/4.0/). 